\title{
Distribution, Secretion and Metabolism of Nitrate in the Rat Lower Digestive Tract
}

\author{
(Metabolic Fate of the Precursors of $N$-Nitroso Compounds. IV)
}

(Received June 10, 1981)

\author{
Hajimu Ishiwata, Hiroko Mizushiro, Ayako SAKaI and Akio Tanimura
}

(National Institute of Hygienic Sciences: 18-1, kamiyoga 1-chome, Setagaya-ku, Tokyo)

\begin{abstract}
The metabolic fate of nitrate in the lower digestive tract was investigated using Wistar male rats. Little or no nitrate or nitrite was detected in the contents of the digestive tract except that $1232 \pm 208 \mathrm{ppm}$ of nitrate was found in the stomach contents when rats were fed on a diet containing $5000 \mathrm{ppm}$ of nitrate for a week. The secretion of blood nitrate into the lower digestive tract was clearly observed by replacement of the contents with saline in ligated sections of the tract; no nitrate was detected in any ligated sections with contents, but the lower small intestine, cecum and large intestine filled with saline contained $23 \pm 13,35 \pm 6$ and $46 \pm 12 \mathrm{ppm}$ of nitrate, respectively, at $15 \mathrm{~min}$ after the in jection of $5 \mathrm{mg}$ of nitrate into the abdominal vein.

Nitrate injected into the lower digestive tract was rapidly reduced to nitrite by the contents. Upon simultaneous injection of $250 \mu \mathrm{g}$ each of nitrate and dimethylamine into ligated sections with contents, the formation of $N$-nitrosodimethylamine was observed at the level of $10 \sim 51 \mathrm{ppb}$. Rapid absorption of $N$-nitrosodimethylamine from the sections was also observed.
\end{abstract}

Key words: rat; digestive tract; nitrate; nitrite; secretion of nitrate; absorption of nitrate; $N$-nitrosodimethylamine; small intestine; cecum; large intestine

Ingested nitrate is known to be reduced to nitrite, a precursor of carcinogenic $N$ nitroso compounds, in human saliva ${ }^{1 \sim 6)}$, stomach $^{\text {() }}$ and infected urinary bladder ${ }^{8)}$, but nitrite had been considered not to be present in the lower intestinal tract since nitrate is absorbed from the upper small intestine and excreted rapidly into urine ${ }^{9 \sim 11)}$. In 1978, however, Tannenbaum et al. ${ }^{12)}$ reported the presence of nitrate and nitrite in human feces and intestinal contents. They suggested that these ions were formed by bacterial heterotrophic nitrification from ammonia or organic nitrogen compounds in the upper, aerobic portion of the intestine. On the other hand, Witter et al. ${ }^{13 \sim 15)}$ reported that blood nitrate was secreted into the lower digestive tract in humans and rats. The origin(s) of intestinal nitrate and nitrite is disputed by Tannenbaum and Witter et al. ${ }^{16)}$, and there has been no report by any other investigator.

One source of intestinal nitrate may be secretion, since nitrate is secreted into saliva ${ }^{3)}$. In the present paper, we confirmed the secretion of blood nitrate into the lower intestinal tract as described by Witter et al. ${ }^{14), 15)}$, and studied the formation of $N$-nitrosodimethylamine (NDMA) in the tract and its absorption from the lower small intestine, cecum and large intestine in rats.

\section{Materials and Methods}

\section{Animals}

Male Wistar rats, 8- to 9-week-old, were purchased from Shizuoka Union for Experimental Animals, Shizuoka. The rats were fed on Funabashi solid diet MM-1 (Funabashi Farm, Chiba) containing $0.1 \mathrm{ppm}$ of nitrite and $15 \mathrm{ppm}$ of nitrate for more than one 
week. The breeding room was maintained at $25^{\circ} \mathrm{C}$ and $60 \%$ humidity.

\section{Surgical manipulations}

Rats were anesthetized by ip injections of $40 \mathrm{mg}$ of sodium pentobarbital $/ \mathrm{kg}$ body weight and the abdominal cavity was opened.

1) Distribution test The digestive tract was excised and the stomach, small intestine, cecum and large intestine were separated. The small intestine was cut into four equallength portions. The excision was carried out in the morning.

2) Secretion test The lower small intestine and the large intestine were ligated, without closing the blood vessels. The length of the ligated section was about $4 \mathrm{~cm}$. In the cecum, the ileo-cecum valve and the site of the cecum-colon connection were ligated. A small hole was made in the ligated section, the intestinal contents were washed out with a small portion of saline, and then the hole was ligated. The ligated sections of the small and large intestines and the ligature of the cecum were injected with 0.25 and $2 \mathrm{ml}$ of saline, respectively, to replace the intestinal contents. A solution of $5 \mathrm{mg}$ of nitrate in 0.25 $\mathrm{ml}$ of water was injected into the abdominal vein.

3) Formation test for nitrite and NDMA Into the loops of the lower small intestine, cecum and large intestine ligated with blood vessels, $0.25 \mathrm{ml}$ of solution containing $250 \mu \mathrm{g}$ of nitrate was injected to test for the formation of nitrite, and $250 \mu \mathrm{g}$ each of nitrate and dimethylamine in $0.25 \mathrm{ml}$ of water was injected to test for the formation of NDMA.

4) Absorption test for NDMA Into the ligated sections of the lower digestive tract, from which the contents had been washed out (see Excretion test), $250 \mu \mathrm{g}$ of NDMA was injected.

Blood specimens were obtained by cardiopuncture.

\section{Analytical methods}

1) Nitrite and nitrate The contents of the digestive tract or ligated sections were washed out with $10 \mathrm{ml}$ of $0.2 \mathrm{~N}$ sodium hydroxide solutions, and $10 \mathrm{ml}$ of $2 \%$ zinc sulfate solution was added to the contents. The mixture was centrifuged and the supernatant was obtained. Next, $2 \mathrm{ml}$ of $2 \%$ potassium alum solution was added to $15 \mathrm{ml}$ of the supernatant, and the volume was made up to $25 \mathrm{ml}$ with $1 \%$ ammonium acetate solution previously adjusted to $\mathrm{pH} 9$ with $10 \%$ ammonia water. After filtration through a filter paper, nitrite was determined by colorimetry with Griess reagent ${ }^{17)}$, and nitrate was determined by the cadmium column reduction method ${ }^{17)}$.

2) NDMA NDMA was determined by the method described by Yamamoto et al. ${ }^{18)}$ First, $0.5 \%$ of sulfamic acid solution was added to the contents of the digestive tract or blood, and then steam distillation was performed under alkaline conditions. NDMA in the distillate was extracted with dichloromethane. The solvent layer was evaporated under reduced pressure, and then concentrated to $1 \mathrm{ml}$ under a nitrogen gas stream. NDMA in the concentrate was determined by gas chromatography with a thermal energy analyzer (GCTEA). The conditions of GC-TEA were as follows: gas chromatograph, Shimadzu GC$6 \mathrm{AM}$; column, $1.5 \mathrm{~m}$ of $10 \%$ PEG $20 \mathrm{M}$ on Gaschrom P; column, injection port and furnace temperatures, $110^{\circ} \mathrm{C}, 140^{\circ} \mathrm{C}$ and $550^{\circ} \mathrm{C}$, respectively; carrier gas, argon; trap, liquid nitrogendichloromethane mixture.

\section{Results}

\section{Distribution of nitrate and nitrite in the gastro-intestinal tract}

The concentrations of nitrate and nitrite in the contents of the rat stomach, small intestine, cecum and large intestine are shown in Table 1.

Less than $4 \mathrm{ppm}$ of nitrate were observed in the contents of the upper digestive tract and $0.1 \mathrm{ppm}$ of nitrite was observed only in the stomach contents of the rats fed on the basal diet. In the stomach contents of the rats fed on the diet supplemented with 5000 ppm nitrate for a week, $1232 \pm 208 \mathrm{ppm}$ of nitrate and $6.6 \pm 8.2 \mathrm{ppm}$ of nitrite were detected, but the concentrations of nitrate and nitrite in the intestinal contents were less than $5 \mathrm{ppm}$, and neither nitrate nor nitrite was detected in the cecum. Serum nitrite and nitrate levels of the rats fed on the nitrate-supplemented diet were $1.0 \pm 0.3$ and $72 \pm 7 \mathrm{ppm}$, whereas those in the rats fed on basal diet were $0.8 \pm 0.1 \mathrm{ppm}$ and not detect. 
Table 1. Distribution of Nitrite and Nitrate in the Contents of the Rat Digestive Tract

\begin{tabular}{|c|c|c|c|c|c|c|c|c|c|}
\hline & & \multicolumn{8}{|c|}{ Concentration, ppm (mean \pm S.D., $n=5)$} \\
\hline & & \multirow{2}{*}{ Stomach } & \multicolumn{4}{|c|}{ Small intestine*1 } & \multirow{2}{*}{ Cecum } & \multirow{2}{*}{$\begin{array}{l}\text { Large } \\
\text { intestine }\end{array}$} & \multirow{2}{*}{ Serum } \\
\hline & & & 1 & 2 & 3 & 4 & & & \\
\hline \multirow{2}{*}{$\begin{array}{l}\text { Basal } \\
\qquad \text { diet }^{* 2}\end{array}$} & $\mathrm{NO}_{2}^{-}$ & $0.1 \pm 0.1$ & $\mathrm{ND}^{* 4}$ & ND & ND & ND & ND & ND & $0.8 \pm 0.1$ \\
\hline & $\mathrm{NO}_{3}^{-}$ & $4 \pm 2$ & $4 \pm 2$ & $2 \pm 1$ & $1 \pm 1$ & $\mathrm{ND}^{* 5}$ & ND & ND & ND \\
\hline $\begin{array}{l}\text { Nitrate } \\
\text { added }\end{array}$ & $\mathrm{NO}_{2}^{-}$ & $6.6 \pm 8.2$ & 4. $4 \pm 1.1$ & 1. $6 \pm 1.0$ & $4.6 \pm 2.8$ & $0.8 \pm 1.2$ & ND & ND & $1.0 \pm 0.3$ \\
\hline $\operatorname{diet}^{* 3}$ & $\mathrm{NO}_{3}^{-}$ & $1232 \pm 208$ & ND & $3 \pm 3$ & $3 \pm 3$ & $1 \pm 3$ & ND & $3 \pm 1$ & $72 \pm 7$ \\
\hline
\end{tabular}

*1 The small intestine was cut into four equal lengths, and numbered from the upper to the lower part.

*2 The basal diet contained $0.1 \mathrm{ppm}$ of nitrite and $15 \mathrm{ppm}$ of nitrate.

*3 Five grams of nitrate (sodium salt) were added to $1 \mathrm{~kg}$ of the basal diet.

*4 less than $0.1 \mathrm{ppm}$

*5 less than $1 \mathrm{ppm}$

able, respectively.

2. Secretion of blood nitrate into the lower digestive tract

The secretion of blood nitrate into the ligated sections of the small intestine, cecum and large intestine was clearly observed (Fig. 1). The maximum level of nitrate was observed in each case at $15 \mathrm{~min}$ after the intravenous injection of $5 \mathrm{mg}$ of nitrate, and then the nitrate level decreased.

Table 2 shows the effect of the intestinal contents on the concentration of nitrate in the ligated sections. On intravenous injection of $5 \mathrm{mg}$ of nitrate, $23 \pm 13,35 \pm 6$, and $46 \pm 12 \mathrm{ppm}$ of nitrate were detected at 15 min in the ligated sections of the small intestine, cecum, and large intestine, respectively, whose contents had been replaced with saline, though no nitrate was detected in the contents themselves if replacement with saline was not carried out. Little nitrate secretion into the saline in the ligated sections was observed when $0.25 \mathrm{ml}$ of saline alone was intravenously injected in place of nitrate solution. Serum nitrate concentrations at $15 \mathrm{~min}$ after the injection of $5 \mathrm{mg}$ of nitrate were $65 \pm 9$ and $69 \pm 9 \mathrm{ppm}$. These values were similar to those $(72 \pm 7 \mathrm{ppm})$ in rats fed on the diet containing $5000 \mathrm{ppm}$ of nitrate for a week (Table 1). The nitrate concentration in the serum obtained from the rats injected with saline alone was $4 \pm 7 \mathrm{ppm}$.

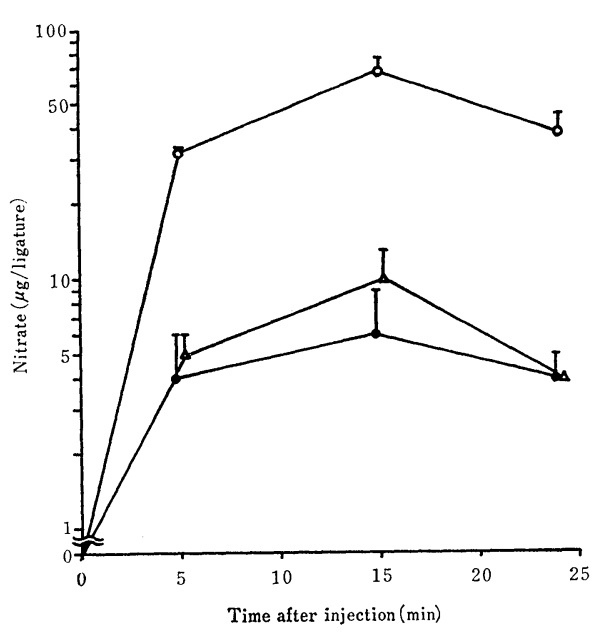

Fig. 1. Secretion of blood nitrate into the ligated sections of the lower intestinal tract

--o: small intestine

○-०: cecum

$\triangle-\triangle$ : large intestine

Five milligrams of nitrate were injected into the abdominal vein. The contents of the ligated sections had previously been replaced with saline.

3. Reduction of the nitrate injected into the ligated sections

Figure 2 shows the decrease of nitrate and the formation of nitrite in the ligated section of the lower digestive tract into which 0.25 $\mathrm{ml}$ of solution containing $250 \mu \mathrm{g}$ of nitrate had been injected. The nitrate injected into 
Table 2. Effect of the Contents in the Ligated Sections on the Concentration of Secreted Nitrate

\begin{tabular}{|c|c|c|c|c|}
\hline \multicolumn{2}{|l|}{ Content } & Intact & \multicolumn{2}{|c|}{ Substituted with saline } \\
\hline \multicolumn{2}{|c|}{ Administration } & Nitrate ${ }^{* 1}$ & Nitrate*1 & Saline*2 \\
\hline \multicolumn{2}{|l|}{ Ligature } & \multicolumn{3}{|c|}{ Concentration (ppm) } \\
\hline Small intestine & $\begin{array}{l}\mathrm{NO}_{2}^{-} \\
\mathrm{NO}_{3}^{-}\end{array}$ & $\begin{array}{c}0.4 \pm 0.9 \\
\text { ND }\end{array}$ & $\begin{array}{c}1.0 \pm 1.4 \\
23 \pm 13\end{array}$ & $\begin{array}{c}0.2 \pm 0.4 \\
3 \pm 7\end{array}$ \\
\hline \multirow[t]{2}{*}{ Cecum } & $\mathrm{NO}_{2}^{-}$ & ND & $0.1 \pm 0.2$ & $0.1 \pm 0.1$ \\
\hline & $\mathrm{NO}_{3}^{-}$ & $\mathrm{ND}$ & $35 \pm 6$ & $1 \pm 1$ \\
\hline \multirow[t]{2}{*}{ Large intestine } & $\mathrm{NO}_{2}^{-}$ & ND & $0.8 \pm 1.4$ & $1.1 \pm 1.7$ \\
\hline & $\mathrm{NO}_{3}^{-}$ & $\mathrm{ND}$ & $46 \pm 12$ & $8 \pm 9$ \\
\hline Serum & $\begin{array}{l}\mathrm{NO}_{2}^{-} \\
\mathrm{NO}_{3}^{-}\end{array}$ & $\begin{array}{c}2.0 \pm 0.9 \\
69 \pm 9\end{array}$ & $\begin{array}{c}\text { ND } \\
65 \pm 9\end{array}$ & $\begin{array}{c}0.4 \pm 0.8 \\
4 \pm 7\end{array}$ \\
\hline
\end{tabular}

The ligated sections were excised at $15 \mathrm{~min}$ after the injection of nitrate.

*1 Five milligrams of nitrate were injected into the abdominal vein.

*2 Saline $(0.25 \mathrm{ml})$ alone was injected in place of nitrate solution.

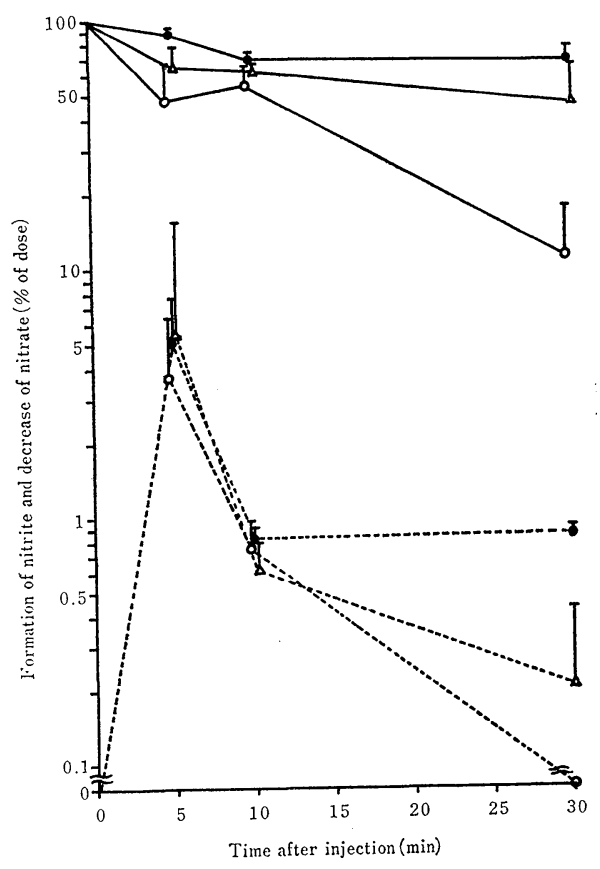

Fig. 2. Decrease of nitrate and formation of nitrite in the ligated sections of the lower digestive tract

-: small intestine

$\mathrm{O}$ : cecum

$\triangle$ : large intestine

- remaining nitrate

- - : nitrite calculated as nitrate

Nitrate, $250 \mathrm{mg}$, was injected into the ligated sections.
Table 3. Formation of NDMA in the Ligated Sections of the Lower Digestive Tract

\begin{tabular}{l|cc}
\multicolumn{1}{c|}{ Ligature } & $\begin{array}{c}\text { Test } \\
\text { group }\end{array}$ & $\begin{array}{c}\text { Control } \\
\text { group*2 }\end{array}$ \\
\hline \multirow{2}{*}{ Small intestine } & Concentration $(\mathrm{ppb})$ \\
\cline { 2 - 3 } Cecum & $51 \pm 26$ & $\mathrm{ND}^{* 3}$ \\
Large intestine & $10 \pm 5$ & $\mathrm{ND}^{* 4}$ \\
& $34 \pm 24$ & $\mathrm{ND}^{* 3}$ \\
& \multicolumn{2}{|c}{ (mean \pm S.D., $\mathrm{n}=5)$}
\end{tabular}

*1 Both $250 \mu \mathrm{g}$ of nitrate and $250 \mu \mathrm{g}$ of DMA were simultaneously injected into the ligated sections.

*2 Water was injected in place of nitrate and DMA.

*3 less than $10 \mathrm{ppb}$

*4 less than $2 \mathrm{ppb}$

the ligated sections was rapidly lost within $30 \mathrm{~min}$ in the order of cecum, large intestine and small intestine, and $3.7 \pm 2.8,5.5 \pm 10.0$ and $5.1 \pm 2.7 \%$, respectively, of the nitrate injected were observed as nitrite at $5 \mathrm{~min}$ after the injection of nitrate. These values correspond to $2.2 \pm 2.1,13.0 \pm 22.8$ and $14.3 \pm$ $8.3 \mathrm{ppm}$, respectively, of nitrite in the contents. The nitrite decreased to less than $1 \%$ after $10 \mathrm{~min}$.

4. Formation of NDMA in the lower digestive tract

Table 3 shows the concentrations of NDMA 

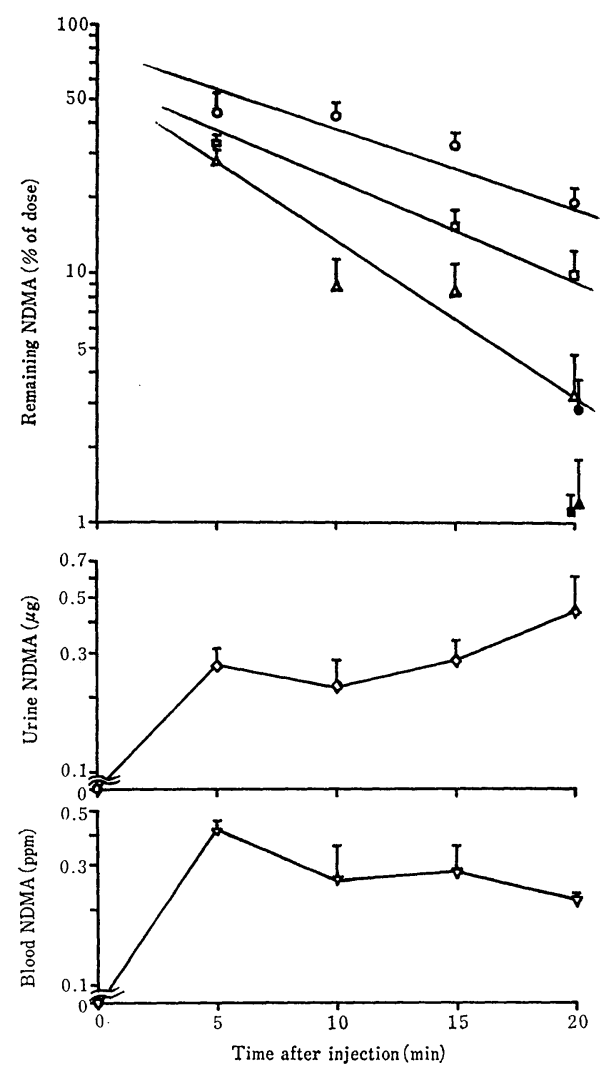

Fig. 3. Disappearance of NDMA from the ligated sections of the lower digestive tract and its appearance in the blood and urine

$$
\begin{aligned}
& \square: \text { small intestine } \\
& \bigcirc: \text { cecum } \\
& \triangle: \text { large intestine } \\
& \diamond: \text { urine } \\
& \nabla: \text { blood }
\end{aligned}
$$

NDMA, $250 \mu \mathrm{g}$, was injected into the ligated sections. The symbols $\boldsymbol{\bullet}$, and $\mathbf{A}$ indicate the remaining ratio $(\%)$ of dose in the tissues of the ligated sections of the small intestine, cecum and large intestine, respectively, after $20 \mathrm{~min}$.

in the contents of the ligated lower digestive tract $20 \mathrm{~min}$ after the injection of nitrate and DMA into the ligated sections. No NDMA was detected in any ligated sections of the control rats, but $51 \pm 26,10 \pm 5$ and $34 \pm 24$ $\mathrm{ppb}$ of NDMA were detected in the ligated sections of small intestine, cecum and large intestine, respectively, of the treated rats.

5. Absorption of NDMA from the lower digestive tract

The NDMA injected into the ligated lower digestive tract rapidly disappeared from the contents; the disappearance curves of NDMA from the contents of the ligated small intestine, cecum and large intestine were all monoexponential. The amounts remaining in the contents were $9.9 \pm 2.6,19.5 \pm 2.8$ and $3.3 \pm 1.5 \%$ of the dose in the small intestine, cecum and large intestine, respectively, at $20 \mathrm{~min}$ after the injection. On the other hand, the remaining amounts of NDMA in the tissues of the small intestine, cecum and large intestine from which the contents had been washed out with $0.5 \%$ sulfamic acid solution were $1.1 \pm 0.2,2.9 \pm 0.9$ and $1.2 \pm 0.6$ $\%$ of the dose, respectively. The concentration of NDMA in whole blood after the simultaneous injection of NDMA into the ligated small intestine, cecum and large intestine (total dose, $750 \mu \mathrm{g}$ ) reached a maximum at $5 \mathrm{~min}$ and then decreased gradually, but that of urinary NDMA continued to increase even after 5 min.

\section{Discussion}

The distribution of nitrate and nitrite in the digestive tract in rats was reported by Witter et $a l .{ }^{14), 15)}$, who suggested that nitrate ingested orally appeared in the lower digestive tract in germ-free rats but not in conventional ones. They detected 12.0, 5.4 and $9.9 \mathrm{ppm}$ of nitrate in the small intestine, cecum and large intestine, respectively, of germ-free rats and $5.6,0$ and $0.7 \mathrm{ppm}$ of nitrate in those of conventional rats when drinking water containing $1000 \mathrm{ppm}$ of nitrate was supplied. The present results (shown in Table 1), obtained with conventional rats, coincide well with the findings of Witter et al. It is known that nitrate is absorbed in the upper small intestine in conventional guinea pigs ${ }^{19)}$ and germ-free rats ${ }^{14), 15)}$. These results show that a portion of the nitrate ingested is reduced to nitrite in the small intestine in conventional rats. It is considered that the nitrate ingested with foods does not reach the lower intestine directly as a result of absorption at the upper portion of the intestine and reduction by intestinal bacteria. On the other hand, absorbed nitrate was secreted into the lower part of the small 
intestine, cecum and large intestine, and was reduced there to nitrite. In the case of the ligated sections in which the contents had been replaced with saline, secreted nitrate concentrations reached 23 to $46 \mathrm{ppm}$ when $5 \mathrm{mg}$ of nitrate was injected intravenously. Serum nitrate at $15 \mathrm{~min}$ was $65 \pm 9 \mathrm{ppm}$, and the concentration was at the same level as that of rats fed on the diet containing 5000 $\mathrm{ppm}$ of nitrate for a week. However, no nitrate was detected in the ligated sections with intestinal contents. This can be expplained in terms of the results shown in Table 2. The nitrate present in the contents of the intestines was rapidly reduced to nitrite, and nitrite also decreased rapidly.

The formation of NDMA was observed after the simultaneous injection of nitrate and DMA into the ligated sections of the small intestine, cecum and large intestine, although the doses were relatively high. The sources of DMA in the intestinal contents are expected to be DMA in the ingested food $^{20), 21)}$ and DMA formed in the digestive tract by intestinal bacteria ${ }^{22), 23)}$. Wang et $a l{ }^{24)}$ found nitrosamines in normal human feces. The NDMA formed in the lower digestive tract may be harmful because the carcinogen was rapidly absorbed from the lower small intestine, cecum and large intestine, and appeared in the blood.

In the present work, the secretion of nitrate into the lower digestive tract and the reduction of nitrate to nitrite in the tract were confirmed, but the formation of nitrate and nitrite by nitrification remains to be investigated.

This work was supported in part by a Grantin-Aid for Cancer Reserch (53-1) from the Ministry of Health and Welfare.

\section{References}

1) Tannenbaum, S. R., Sinskey, A. J., Weisman, M., Bishop, W.: J. Natl. Cancer Inst., 53, $79 \sim 84$ (1974).

2) Ishiwata, H., Boriboon, P., Nakamura, Y., Harada, M., Tanimura, A., Ishidate, M.: J. Food Hyg. Soc. Japan, 16, 19 24 (1975).
3) Ishiwata, H., Tanimura, A., Ishidate, M.: ibid., 16, 89 92 (1975).

4) Ishiwata, H., Boriboon, P., Harada, M., Tanimura, A., Ishidate, M.: ibid., 16, 93 98 (1975).

5) Spiegelhalder, B., Eisenbrand, G., Preussmann, R.: Fd Cosmet. Toxicol., 14, 545 548 (1976).

6) Tannenbaum, S. R., Weisman, M., Fett, D.: ibid., 14, 549 552 (1976).

7) Sander, J., Seif, F.: Arzneimittel-Forsch., 19, 1091 1093 (1969).

8) Hichs, R. M., Gough, T.A., Walters, C. L.: IARC Sci. Publ. No. 19 "Environmental Aspects of $N$-Nitroso Compounds" pp. 465 475 (1978), Lyon.

9) Ishiwata, H., Mizushiro, H., Tanimura, A., Murata, T.: J. Food Hyg. Soc. Japan, 19, 318 322 (1978).

10) Radomsky, J. L., Palmiri, C., Hearn, W. L: Toxicol. Appl. Pharmacol., 45, 63 68 (1978).

11) Maruyama, S., Shimizu, S., Muramatsu, K.: J. Food Hyg. Soc. Japan, 20, 276 282 (1979).

12) Tannenbaum, S. R., Fett, D., Young, V. R.: Science, 200, 1487 1489 (1978).

13) Witter, J.P., Gatley, S. J., Balish, E.: ibid., 204, 411 413 (1979).

14) Witter, J. P., Balish, E.: Appl. Environ. Microbiol., 38, 861 869 (1979).

15) Witter, J.P., Balish, E., Gatley, S. J.: ibid., 38, 870 878 (1979).

16) Tannenbaum, S. R., Witter, J. P., Gatley, S. J., Balish, E.: Science, 205, 1333 1337 (1979).

17) Harada, M., Ishiwata, H., Nakamura, Y., Tanimura, A., Ishidate, M.: J. Food Hyg. Soc. Japan, 16, 11 18 (1975).

18) Yamamoto, M., Yamada, T., Tanimura, A.: Fd Cosmet. Toxicol., 18, 297 299 (1980).

19) Ishiwata, H., Mizushiro, H., Tanimura, A., Takahashi, A., Omori, Y., Murata, T.: J. Food Hyg. Soc. Japan, 18, 524 528 (1977).

20) Kawamura, T., Sakai, K., Miyazawa, F., Wada, H., Ito, Y., Tanimura, A.: ibid., 12, 192 197 (1971).

21) Singer, G. M., Lijinsky, W.: J. Agric. Food Chem., 24, 550 553 (1976).

22) Asatoor, A. M., Simenhoff, M.L.: Biochem. Biophys. Acta, 111, 384 392 (1965).

23) Asatoor, A. M., Chamberlain, M. J., Emmerson, B. T., Johnson, J. R., Levi, A. J., Milne, M. D.: Clin. Sci., 33, 111 124 (1967).

24) Wang, T., Kakizoe, T., Dion, P., Furrer, R., Varghese, A. J., Bruce, W. R.: Nature, 276, $280 \sim 281$ (1978). 